\title{
Missional theology and social development
}

\author{
H Jurgens Hendriks \\ Department of Practical Theology \& Missiology \\ University of Stellenbosch
}

\begin{abstract}
The article describes a theological paradigm shift taking place in congregations in South Africa that empower them to become involved in development work as a way of serving their neighbor. It also opens the possibility of working interdisciplinary without compromising theological and faith values. The perspectives and assumptions of the new paradigm are outlined and the basic methodology of doing theology is described. The new paradigm is a missional one, taking the focus on God as its point of departure and describing the identity and purpose of the church by looking at God's identity and plan or mission with creation and humankind. Social development is seen as being in line with God's mission and as such the church should not have difficulty in working with those who pursue the same goals.
\end{abstract}

\section{INTRODUCTION}

The purpose of this article is to critically describe the change in theological paradigm that is taking place in post-apartheid South Africa, which is leading to a new openness in the church to becoming involved in development. The church, especially the Dutch Reformed Church (DRC) and other mainline denominations, are, in a word, moving away from being an institutionalised church in the wake of the Enlightenment to becoming a missional church in the wake of an emerging ecumenical missionary paradigm (Bosch 1991:x-xi). The shift is due to a new hermeneutical perspective on doing theology which is in no uncertain way changing the face of theology and the way the church is understood and functioning. As such, it has opened the door to the church once again becoming socially involved in a new and unique way (Stark 1997:73-94).

This article is based on interdisciplinary cooperation and research between a number of faculties and departments at the University of 


\section{Missional theology and social development}

Stellenbosch, and wants to describe the theological methodology and the theological ethos that has given theology the openness to work with other disciplines without compromising its basic faith assumptions (Erasmus et al 2006:293-311; Hendriks et al 2004:380-402). The article will concentrate on describing the advent of missional theology and how it leads to a methodology of doing theology that ultimately engages congregational members in becoming involved in society.

One reason for describing the theological methodology and the way theology "translates" the concepts and language of other disciplines into its own hermeneutical sphere is to understand and respect research partners. The challenges we face in Southern Africa are so enormous that only a holistic approach will be able to make a difference. In this the church, with the theology that undergirds its ministry, is a key role player. It reaches more people on a weekly basis than any other organisation. It has a stronger infrastructure than even the government in connecting, serving and influencing people (Symington 2005:16-165; Castells 2004:303-418). An article in Die Burger of 16 September 2005 referred to a Gallup/BBC poll, which reported that in the 68 countries where the poll was conducted, the average level of trust in politicians was $13 \%$, while spiritual leaders received a $33 \%$ level of trust. In Africa, the trust in spiritual leaders is $74 \%$ !

One assumption of this article is that the church can play a major role in addressing the countless problems that confront Southern Africa (Radoli 1998:257), but not if its theological methodology still adheres to the old clerical paradigm. We believe theology is contextual and missional by its very nature and that it should address society's issues and problems in a holistic way. We believe that the church has a crucial role to play in, amongst other issues, providing an infrastructure for an African Renaissance (Makgoba 1999). Similarly, racial and other problems can be overcome only if Christians have a holistic approach to their vocation and witness. The church, however, should not be ideologically driven by political, economic, racial or other motives. Its theology should be sound.

The Western world is experiencing a paradigm change. This is happening in countries such as Britain (Brierley 2000) and the Netherlands (Dekker 2000) which have profoundly influenced South Africa. The same trends, but with a different twist, are discernible in our country (Froise \& Hendriks 1999:1-105; Symington 2005:16-166; Hendriks \& Erasmus 2003, 2005.), where immense changes are taking place. The paradigm change is having an enormous global influence on the church and its ministry (Bosch 1991:349-520; Hall 1996:201-340; Mead 1996; Sweet 1999; Schwarz 1999) 
and has led to a southward shift in the centre of gravity of Christianity (Jenkins 2002; Walls 2002; Bediako 1995; Sanneh 2003).

Theologically, one can describe the paradigm change as moving away from an ontological to a hermeneutical paradigm. This means a move away from a one-dimensional, rational, subject-object approach, which leads to a deductive style and a positivistic, even triumphalist, attitude in doing theology. One result of this approach was the clerical paradigm. A hermeneutical approach is more sensitive, with the understanding that our theological viewpoints are relative to our context, that theology always has a limited viewpoint and a limited grasp of wider realities. A hermeneutical approach can lead to greater humility and a greater dependence on God's grace and guidance.

A look at current (social) research methodologies points in the same direction. Grounded theory and participatory action research De Vos 1998:265-276, 406-417) are becoming more popular than the old deductive styles that worked with well-established theories. Top-down leadership styles and research methodologies do not solve problems, provide answers or lead to transition on the ground. In a New World new research methodologies are required. This also applies to congregations and the way they do theology (Ploeger 1999:69-93) .

The movement that profoundly influenced the theological methodology outlined below is the work done by the Gospel and Our Culture Network and the Partnership for Missional Church. The life and work of Lesslie Newbigin and David Bosch led to a critical theological engagement with the philosophical and epistemological roots of modernity, of Western and Reformed theology and culture. The notion that theology is missional in its very essence is the basis of this approach (Hunsberger \& Van Gelder 1996; Guder 1998). In the Network for African Congregational Theology (NetACT) a group of theologians from Southern Africa formed a network to translate the missional church principles to doing theology in Africa. What follows below is basically a summary of their work (Hendriks 2004:19-34).

\section{PERSPECTIVE AND ASSUMPTIONS}

Theology is a faith-based endeavour. The following are the basic assumptions on which a missional methodology and its stance on development are based. Theology is basically one (it should not be divided by its many sub-disciplines) and missionary by its very nature (Bosch 1991:389-393). Theology's epistemological core is a faith-based focus on the Triune God who reveals Himself as a fountain of sending love (missio Dei) through Scripture and through the Holy Spirit's ongoing, life-giving and not-to-be-manipulated work. 


\section{Missional theology and social development}

The Holy Spirit is the power in faith communities, although these communities do not control it. Change refers to external and physical changes, but the work of the Holy Spirit leads to conversion, that is, a form of transformation that changes attitudes and intentions. ${ }^{1}$ Theology focuses on God, but it is also accountable to three public sectors: the academy, society and the church (Tracy 1981:3-31; Hanson 1986:525-527). The discussion below will explain why.

The missional paradigm pursues a missional and practical ecclesiology: it develops a methodological strategy on how to be a contextually relevant church. It has a correlational-hermeneutical approach to (practical) theology in which it observes different perspectives and initiates a dialogue between them (Ploeger 1999:69-93). Its ecclesiology focuses on congregations, also called "faith communities", which are the basic building blocks of the church. Denominational and ecumenical manifestations depend on congregations (Burger 1999:10). Doing theology and being church is a process, where the context influences all theological formulations and institutional designs. Thus, practical theology and theology as such are contextual; the church is missional, not static - to a certain extent it is always in suspension, moving. Its only foundation is the grace that it receives from a Triune, active God. Different perspectives should contribute to the process of doing theology, that is: historical, systematic and contextual perspectives should always be "juggled" in the discernment process.

Missional theology and ecclesiology will focus on a contextual praxis, that is, on a reflective engagement as faith communities in the world. The methodology developed in this endeavour is the specialized field of practical theology (Hendriks 2004:19). The implication of this stance is that doing theology shall never claim to have final answers as to the exact nature of God, the church, or to many theological questions, but it shall always be able to witness about what it believes. This ecclesiology will never deign to give anybody a blueprint about being church, but it will provide a methodology to discern how to participate in the missional praxis of the Triune God and, as such, how to become what God wants his people to be: his image, his body.

\footnotetext{
${ }^{1}$ While the researcher was writing this article, newspaper and television reports covered the story of the former minister of police and "strongman" of the apartheid government Adriaan Vlok. It may serve as an illustration of what we are describing. Vlok, on his own accord, requested to see the Director General of the Presidency, Pastor Frank Chikane. The purpose was to personally ask for forgiveness and to wash his feet as a ceremonial gesture. Several attempts on Chikane"s life were made by the very forces that Vlok commanded. Vlok"s request was that it should be a private affair without media coverage. Chikane, however, was so touched by the sincerity of the deed that he asked Vlok"s permission to make it known. The newspapers subsequently discovered that Vlok did likewise in Mamelodi, a Black township, where he went to wash the feet of black women whose loved ones were "eliminated" during the struggle days. The usually cynical newsmen found this a remarkable reconciliatory gesture (Die Burger Sept 11, 2006).
} 
The theological anthropology of this approach to doing theology is pneumatological and eschatological by nature. Pneumatological, because it believes that the Holy Spirit renews people, because, in his grace and mercy, the Father has chosen to redeem people through the mediating work of his Son, Jesus Christ; and eschatological, in the sense that people are transformed through the power of the Holy Spirit to be moral beings with certain gifts and responsibilities, sharing in God's missional praxis. Such an approach does not resolve the tension between inherent sinfulness and being a new person in Christ, but emphasizes that, through the indwelling of the Holy Spirit, growth is made possible in a lifelong process of sanctification. Faith communities are to be signs of a new creation (Louw 1998:121-168).

Missional theology believes that there is a strong link between anthropology and ecology. To make a distinction between humankind and nature, as if humankind has dominion over nature and can use and abuse it indiscriminately, is a fatal error - one that held sway in Western society for at least the past 500 years. Theology that is not sensitive ecologically is similar to a theology that concentrates on either evangelism or social issues, a theology that makes a distinction between body and soul. A theology that distinguishes between people and earth, humans and nature, is equally unbalanced (Rasmussen 1996).

Lastly, this researcher believes that denominational diversity should be seen as a blessing in disguise. The lack of unity and love amongst Christians is deplorable and, in that sense, disunity and pluralism are negative. However, when Christians work together, they have much to learn from one another. A correlational-hermeneutical approach to theology may more easily escape from either fundamentalist or positivist presuppositions and as such may lead to a new era in ecumenical relationships as well as openness to work with people of other faiths.

We now turn to explain in more detail the tenets of this missional perspective and the theological methodology it uses. In explaining the way it views theology, its willingness to become involved in social development will become clear.

\section{THEOLOGY DEFINED}

A missional theology believes that theology is about discernment (Phlp 1:910). It is a correlational and hermeneutically active dialogue in which the following act as the parameters of the dialogue:

- It first of all asks about God: who is this relationally oriented triune God that reveals himself to the world in and through Scripture? 
- The second question is about identity: this God who created humankind in his image and likeness placed them as his stewards and custodians on earth. Since God is revealed as Creator, as a missional God, the church, Christians, all people, should be seen in that light. God's character and mission form the basis of ecclesiology and anthropology.

- God loved this world and gave his Son to save it (Jn 3:16). God is focused on this world and as such theology should teach students and church members to be actively engaged in understanding this world and serving it.

- To understand God truly (Kelsey 1992:131-160) the faith community should know its own story in order to understand its identity. The Reformers called this sola scriptura implying that Scripture, the Word, should be normative over and against all ideologies.

- The church's mission is that of the Kingdom of God which Scripture describes as a situation where peace and righteousness will reign supreme.

- Theology thus implies a discernment process that takes place when we obediently participate in transformative action and service at different levels: personal, ecclesial, societal, ecological and scientific (a doing, liberating, transformative theology that leads to strategy formation, implementation and an evaluation of progress; a theological praxis!) (Hendriks 2004:19-34; 211-234). ${ }^{2}$

The discussion will now turn to the points outlined above. They function as a set of markers or orientation beacons, such as those used by aeroplanes, for fixing their position and course. The tenets are interwoven and are to be used in the process of doing theology in a living faith community where believers are called to take part in God's missional praxis.

It is important however, to stress at this point that the crucial clue to understanding why a missional theology is open to social development issues

\footnotetext{
${ }^{2}$ Compare this with what Walls says in the context of the necessity of diversity and the crossing of boundaries (2002:79): "The purpose of theology is to make or clarify Christian decisions. Theology is about choices; it is the attempt to think in a Christian way. And the need for choice and decision arises from specific settings in life. In this sense, the theological agenda is culturally induced; and the cross-cultural diffusion of Christian faith invariably makes creative theological activity a necessity."
} 
has been put forward (Elliott 1987). The way a missional theology understands God is by putting God in the centre of everything. The rest follows from this. We will now turn to this aspect.

\section{THEOLOGY IS ABOUT GOD}

The fundamental shift that is taking place in the method of doing theology boils down to moving away from a theology that "obediently analysed" the faith tradition towards an approach that says that the safer way to do theology is to "obediently take part" in God's missional praxis (Guder 1998:4; Burger 1999:55). The older paradigm worked with a subject-object scheme, where the theologian was the subject studying texts about God, the church, et cetera.

The essence of theology, says the missional approach, is to know God, to discern his will and guidance; it is faith seeking understanding (Anselm, Ammerman 1998:23). God is a Triune, missional God. The first premise that undergirds the argument is that mission is an extension or amplification of God's very being. Karl Barth was one of the first theologians to articulate mission, not in the context of ecclesiology or soteriology, but in the context of the doctrine of the Trinity (Bosch 1991:389-390). Missional theology took this lead and that of others who amplified it by saying that theology should be viewed as sharing in the missio Dei. The second premise is that a faith community cannot really understand God in a personal way without taking part in his missional praxis. It is an activity initiated by the sending, missional God who, in his grace and mercy, entered into a covenant with the faith community in order to use it as an instrument of his mission (Bosch 1991:389393, 510-519; Rasmussen 1996:227-316). A third premise that undergirds our argument is that mission, as an extension or amplification of God's very being, has to pay attention to the fact that God is revealed as three persons, triune. This should not simply be objectified and analysed into ontological categories of thought. It has important implications for mission as well as for our understanding of theology. Because God is a community, humankind and faith communities cannot be any different (Hall 1993:55-72, 72 n 47; Newbigin 1995:28-29; Burger 1999:141-143).

In this context "missional" should not be equated with the missionary enterprise associated with Western imperialism and the colonization of countries in the non-Western world. It does not refer to the empirical project where First World churches called, trained and sent missionaries to foreign countries and so-called "unreached peoples". Nor does it refer to the theological discipline that developed around this whole endeavour, or the organisational-institutional structures that were developed for the upkeep of 


\section{Missional theology and social development}

the infrastructure of the "missions". Alan Roxburgh (2005:12) defines missional in the following way:

The word missional was coined to express the conviction that North-America and Europe are now primary "mission fields" themselves. Missional also expresses that God's mission (or missio Dei ... ) is that which shapes and defines all that the church is and does, as opposed to expecting church to be the ultimate self-help group for meeting our own needs and finding fulfilment in our individual lives. If the West is once again a mission field within which the central narratives of the gospel have been either lost or profoundly compromised by other values, then the focus of this mission must be upon placing the God we encountered in Jesus Christ back in the center of our communities of faith that shape and give meaning to our lives.

One of the church's fundamental problems is the notion that mission is an ecclesiocentric activity - an activity of the church along with its other ministries. A Theo centric reconceptualisation is needed (Newbigin 1989:135; Guder 1998:3-7). When viewing mission from the locus of the Trinity, the following facts have important implications: God is the Creator of heaven and earth, and He bestowed the responsibility for taking care of his creation on humankind (Gn 1-2). God's mission (purpose) and his reign involve creation, care, redemption and consummation. Thus, God's mandate and involvement cannot be limited exclusively to the church. He has the power and jurisdiction to extend his mission as He pleases, although Scripture leaves no doubt that, in this enterprise, the church plays a fundamental role.

From this it should be clear that by refocusing theology on the Trinity, and believing that this missional God is the Creator and Redeemer of the earth and its entire people, the whole paradigm of being church changes. This paradigm change will have a profound effect on the church's view of its own mission and, as such, on development. We now turn to consider this point.

\section{THEOLOGY IS ABOUT THE CHURCH}

The basic argument follows from Genesis 1:26-28, where the triune God says the He made humankind in his image and likeness. God placed humans in three relationships: to Himself, to nature and to one another (husband and wife with the responsibility to have children and to be stewards of creation). The family is God's smallest "congregation". The basic presupposition is that one's identity (anthropology), as well as the identity of the church (ecclesiology), is to be derived from God's very being. He created us in his 
likeness, his image. What that entails can only be derived from his (self-) revelation. For this, the Scripture, in its narrative way, is the primary source. God revealed Himself as a purposeful, active God and, in following his guidance, the church learns to do theology and discovers who it is as a congregation of persons and as a body. People are the stewards of God's creation and of his mission! (Hanson 1986:2,10f)

Newbigin (1995; cf McLaren 2000:65-72; Bell 2005:18-36) subtly explained the epistemological paradigm shift behind this way of doing theology. Theology no longer views itself with a mathematical ethos of having the last word about God and more or less everything else. Missional theology is done from the vantage point of a steward following the example par excellence of Jesus Christ Himself. The story of the origin of the church, the metanarrative that shaped the rest of the unfolding story of God's people, the DNA structure of the community of faith, can be found in the self-disclosure and praxis of an initiative-taking God. This story began with the exodus event, as discernible history. God revealed Himself as the God who heard the cries of slaves, who took notice of the suffering of people with no social standing. He called them, they obeyed his call and they became his people. A covenant was established or reconfirmed. By following the acts of the missional God, by listening to the stories of the communities shaped by His revelation and guidance, one begins to discern the identity of the church, his people.

The theological argument is clear. Authentic communal structures constantly develop contextually as the faith community responds to the initiative of a living, purpose-driven God. The arguments of ecclesial hierarchies who want to keep programmes and institutional designs uniform for the sake of good order, usually boil down to predictions of chaos or relativism, if a situation of constant flux is allowed. Biblical and post-biblical history bear testimony to the bitter conflicts that have ensued during transitions. Noteworthy examples are the periods between the judges and the kings ( $1 \mathrm{Sm} \mathrm{12)}$ and the boundary-crossing event of reaching out to the Gentiles (Ac 9-11 \& 15).

The insistence that the essential truth about a faith community is the dynamic relationship between a missional God and a responsive community implies action. Because God is the initiator and sustainer, chaotic relativism is ruled out. However, making the transitions that a changing context requires is never easy. To revise the role and practice of the church in a new context requires the discerning of God's will and receiving his guidance. It often takes considerable effort by a faith community to deal with this process. The church has experienced some rough passages! 
Some of the theological and ecclesiological implications of this perspective help one to understand the openness of the missional church to be involved in social development. The theological clue should be taken from the exodus story and the subsequent metanarrative that form the identity of the faith community. We worship a compassionate, righteous God who took heed of unjust situations and acted in a liberating, transformative way. If the focus, sharpened and directed in worship and through the sacraments, is kept on God, and the community shapes its identity according to his nature, then two fallacies that have dogged the church throughout history can be avoided. They are, on the one hand, other-worldliness, being so spiritual and eschatologically preoccupied that matters on this earth, the pain, suffering and injustice, are avoided. On the other hand, communities can be so "this worldly" and so involved in fighting liberation struggles and setting injustices right that God, his compassion and his missional purpose are not taken into account. Then penultimate or subordinate goals and other motives, ideologies, power - other gods - begin setting the agenda.

The Old Testament prophets and, in particular Jesus Christ, illustrate the antithesis. Their theological compass was set on God's redemptive, missional purpose; therefore they had a different perspective on reality. When the Satan tempted Jesus (Mt 4), he tried to shift Jesus' focus to penultimate personal needs (bread, hunger), honour and power. There is a need for Christians to find a way of being a "radical alternative" in modern culture. This can only happen when they are living according to biblical values (Guder 1998:115-128).

At present, it is important to emphasize the role of the laity who constitutes the church. Ordinary people now have access to one of the most important forms of power: Information (Castells 2004:425). A functional and contextual ecclesiology has become important. The post-modern situation, where individualism, pluralism and relativism abound, forces the church to find ways and means of regrouping into communities of faithful believers who make a deliberate choice to follow Christ and to be an alternative community in a secular world. Gone are the days when a people's church (volkskerk) collaborated with the state, and when it was considered culturally important and profitable to belong to a church. One cannot depend solely on academics or the clergy to lead the way in reforming the church and its ministry. Ours is a society in which traditional modes of authority are no longer influential. This has a direct influence on the way we do theology. One of the assumptions of missional theology is that the church is, primarily, the local church and, as such, is a complete church. Today the laity questions "the authorities". In our society believers must be producers of theology because they are constantly 
confronted with situations in which they must make ethical choices. However, when emphasizing the local church's importance and the laity's role, the significant role of denominational and ecumenical church structures and leadership should not be discarded, but their role, function and style must change (Easum \& Bandy 1997; Hanson 1986:526; Kelsey 1992; Fowler 1995:1; Mouw 1994; West 1994:15-25; Bosch 1991:378-389,470-474; Mead 1996:16-31).

These theological and methodological parameters lie behind the kind of social involvement of many of the faith communities that took part and cooperated in the research and social development practices described in this book. It should be clear that their involvement is a logical consequence of their belief and identity. It helps one to understand on what basis they contributed, but also why they did not feel threatened in working with people of other faiths. This change of attitude in missional churches was supported by the other developments in theology and the way that theology became open to working with other disciplines. The next section will explain this in more detail.

\section{THEOLOGY IS ABOUT THE WORLD}

The basic self-understanding of the church is that it is to be the people of God, the body of Christ, God's stewards of creation, a people in relationship bound to love one another. When things went wrong $(G n 3)$, God so loved this world that He sent his Son to redeem it (Jn 3:16). Christians are called to love their neighbour (Mt 22:23) - and that neighbour is those who need them (Lk 4:10). Since God is a purposeful God, his people have to do likewise and follow the example set by his Son. A faith community is a people called, living in a particular time and place where they are called to witness within the confines of their world. They must answer questions such as: What is happening here? How should we react to whatever comes to our attention, or how should we react to what confronts us? Ethical questions abound in our ever-changing world: What is right and what is wrong? Christians must be able to contribute towards dealing with current vexing problems, locally and contextually. By definition, therefore, Christian theology is contextual for three reasons (Hall 1991:69, 93-110; Newbigin 1989:141-154):

- Theology is a human enterprise;

- It tries to speak of a living (initiative-taking) God who is in a living relation with a dynamic creation; and

- Theology is done as a way of discerning what the church should confess and then practice. 


\section{Missional theology and social development}

In doing theology in Africa, we should be realistic about our situation

(Stremlau 1999:102-104; Castells 2000:68-211), as well as what is happening globally. What are the megatrends and how do they influence Africa? (Bosch 1991; Mead 1991; Rasmussen 1993, 1996; Guder 1998) Asking these questions is part of the discernment process linked to the primary question: how are we to participate in a Triune God's missionary praxis? Theological honesty about the global contextual realities that face Africa will help the church to be a public church, a church that witnesses actively to all spheres of life about the way, the truth and the life.

In many theological schools, theology is done by way of studying traditional texts (systematic theology, creeds), then applying them to a specific situation and congregation. The problem is that, ultimately, one may become disconnected from daily experiences, questions and challenges that confront a congregation's members. Consequently, they are unable to deal with change and transition, and this result in a slow spiritual, institutional decline.

A "critical" interpretation would require an analytical ability and a prophetic stance to understand the present reality in the light of the church's missional vocation. Theology is "problem-posing" (Fowler 1999). To formulate the problem, one must describe it correctly. Research begins here, and methods are needed to conduct the inquiry in a valid and reliable way. Depending on the line of inquiry, the methods used in sociology, geography, psychology, anthropology, economics, philosophy of education, et cetera are helpful. There is an undeniable empirical side to doing theology (Van der Ven 1998).

In this regard Practical Theology and Missiology have been greatly helped by the work of the "Congregational Studies Team" that used the methodology of Sociology of Religion (Carroll et al 1986:21-154; Ammerman et al 1998:40-166; Ammerman 1997, 2005; Hendriks 1992:212-193). In many ways Sociology helped Theology to find the methodology to do empirical work and use the results in the theological discernment process. The missional perspective of theology helps one to understand why cooperation is possible.

\section{THEOLOGY IS ABOUT THE WORD}

Theology is hermeneutical by its very nature. It depends on the interpretations which fallible people try to make of both their reality and what for them, within their belief assumptions, are normative sources such as the Bible, creeds and the Christian tradition. In this endeavour of interpreting normative sources, several actions and role-players have a stake. This is where history, memory, story and tradition are at stake. The biblical disciplines of Old and New Testament studies specialize in understanding the text of the Scriptures; 
Systematic Theology make a systematic compilation of the content of Scripture using different methods; philosophical and comparative religious studies play a role; ethical debates have taken place; and church history tells the ongoing story of the church in the world.

As such, the church is an interpretative community in an ongoing engagement with the remembered patterns of God's praxis. The sedimented rock of this engagement is to be seen in the patterns of the church's worship and practice. Theology would request its research partners to respect its beliefs. Within a missional paradigm there is always openness to being criticized, since theology in the postmodern stance is aware of its fallibility. The church would, however, also claim to witness to society about what it perceives to be in contradiction to its beliefs. The prophetic witness of the church is something that has over many centuries proved its value to society, as its stance against apartheid proved. Remarkable people like Bishop Desmond Tutu illustrate this point (Allen 2006).

\section{THEOLOGY IS ABOUT A MISSION}

The Utopian hopes created by the Enlightenment and modernism seem to have vanished. In a world where the gas ovens of the Second World War, the nuclear threat and the ecological destruction on our planet are fresh memories, people are disillusioned. The impact of AIDS, and the capitalist market economy that is creating a world in which the rich are becoming richer and the poor poorer, are but two indicators of a depressing mood in which hopes for the future are slim (Korten 1995:1).

An important question may be repeated: What is the ultimate assumption on which the whole endeavour of doing theology rests, and what is its epistemological nucleus? The answer to these questions lies beyond the reach of a cognitive, rational argument. This is where statements about faith, belief and religion become necessary. The symbol of the Kingdom of God is such a statement (Bright 1953; Van der Ven 1998:70-71). It points to the belief in a Triune God who created the world and acts in this world for the benefit of its people. In Jesus Christ the Kingdom became flesh and blood. His life and death is intrinsically linked to the creation motive, because in his death and resurrection one finds re-creation, a new creation dawning upon us. Jesus' life and teaching teach us that the Kingdom of God is approaching and that it brings salvation. This is good news for all, especially the poor, the weak, outcasts, the unjust and sinners. It is a dream about the future that invites us to improve our present reality and, as such, is linked integrally to the process of doing theology. 


\section{Missional theology and social development}

Seen in this light, faith communities are bearers of hope. A look at history may raise the question: why did faith communities persevere through so many ages and circumstances? The answer can be found in the unique vision of an entire creation, as an intricate organism created by God for the benefit of all creatures, as a home where they can live to praise and honour their Creator. However, the Christian story is honest about the precarious position of humans on earth. People will be enslaved by serving idols which, ultimately, leads to all the familiar woes experienced on this earth. The Bible, however, also bears witness to a righteous and compassionate God who, in a reliable way, consistently helped those who heeded God's call for repentance and who put their trust in God. To those who follow God, God promises a new future because, in God's very essence, God is a creator, redeemer, sustainer, a God who will not forsake God's mission. God calls people to participate in this venture of restoring a broken world. Those who follow God experience deliverance from many forms of bondage, as well as a new freedom in serving the one Sovereign God. To worship God and to be in communion with God is the source of meaning and hope.

These remarks should be helpful in understanding the strong driving force and hope that can be part of faith communities that serves, amongst other reasons, as the driving force behind their involvement in social development.

\section{THEOLOGY IS ABOUT DISCERNMENT AND ACTION}

The solution to faith communities' questions about how to participate in God's missional praxis is a critical and constructive dialogue of discernment that hermeneutically correlates the following:

- A contextual situation with its problems and challenges;

- the identity of the people of God, and

- the role and purpose, or mission, that they have,

- which flow from their knowledge of Scripture and tradition.

It is a two-dimensional exegesis of the world and the Word that takes place in a gathered faith community who actively rely on God's presence and guidance. It may also be called a fusion of two horizons in which the interpreted social reality and the interpreted Christian normative sources meet in order to provide vision and guidance for an anticipated future (Van der Ven 1998:19; Hanson 1986:523-537; Fowler 1995:6-7). This call for prophetic imagination (Brueggemann 1978), for creative thought, and action in which a 
faith community tries to discern the Holy Spirit's guidance and, in the process, bears witness to present experiences of revelation.

A missional theology does theology by focusing on global, local and particular issues with the intention of doing something about the reality and problems confronting society. It does this because God, in God's coming to us in and through Jesus Christ, initiated something that changed people and formed them into a missional community of people called to love God and their neighbour. As such they try to participate in God's ongoing involvement in moving towards an anticipated future reality. It does so in a vocational way. This active-reflective spiral (praxis) leads to a new formulation of the truth and values that may be systematically expressed in theology in new creeds but, above all, in the life and witness of the church. As such, aspects of the eschatological future are now realized, creating joy and hope.

This hermeneutical, correlative way of doing theology should be expressed on the following levels (Tracy 1981:3-31; Van der Ven 1998:22-23). On a personal leve/ we are called to discern our vocation and become involved as followers or disciples of Jesus Christ. On an ecclesial level we are the body of Christ: a missional church that acts in worship, witness and service. On the level of society, the church has an important role to play (Hauerwas \& Willimon 1989). It must witness to the Gospel of Jesus Christ and proclaim prophetically that justice be done to all. Part of this vocation is to get involved. The scientific leve/ refers to the academic-intellectual aspects of theology (Van der Ven 1998:23). On the ecological level the church as the body of Christ should play its part in being humble custodians of the creation (Rasmussen 1996).

\section{CONCLUSION}

The purpose of this article was to critically describe the change in theological paradigm that is taking place in post-apartheid South Africa. It argued for the involvement of the church in social development. The article described the assumptions and tenets of what is known as a missional theology. Summarising one can say that:

- theology is about the discernment that takes place in a faith community

- that leads to active involvement in church and society

- being a reaction to the presence of a Triune, missional God

- who speaks to us through Scripture and tradition

- in our context

- and who beckons to us from the future. 


\section{Missional theology and social development}

Understanding this concept and methodology of theology opened the way to understanding why and how the church became a valuable partner in social development in post-apartheid South Africa.

\section{Works consulted}

Allen, J 2006. Rabble-rouser for peace. London: Rider.

Ammerman, N T 1997. Congregation \& community. New Brunswick: Rutgers.

Ammerman, N T 2005. Pillars of faith: American congregations and their partners.

Berkeley, CA: University of California Press.

Ammerman, N T, Carroll, J W, Dudley, C S \& McKinney, W 1998. Studying congregations. Nashville, TN: Abingdon.

Bediako, K 1995. Christianity in Africa: The renewal of a non-western religion. New York: Orbis.

Bell, R 2005. Velvet Elvis: Repainting the Christian faith. Grand Rapids, MI: Zondervan.

Bosch, D J 1991. Transforming mission: Paradigm shifts in theology of mission. Maryknoll, NY: Orbis.

Brierley, P 2000. The tide is running out. London: Christian Research.

Bright, J 1953. The Kingdom of God, the biblical concept and its meaning for the church. Nashville, TN: Abingdon.

Brueggemann, W 1978. The prophetic imagination. Philadelphia, PA: Fortress.

Burger, C 1999. Gemeentes in die kragveld van die Gees. Stellenbosch: BUVTON.

Carroll, J W, Dudley, C S \& McKinney, W 1986. Handbook for congregational studies. Nashville, TN: Abingdon.

Carroll, J W, Dudley, C S, \& McKinney, W 1986. Handbook for congregational studies. Nashville, TN: Abingdon.

Castells, M 2004. The power of identity: The information age: Economy, society and culture, volume II, $2^{\text {nd }}$ ed. Oxford: Blackwell.

Castells, M 2000. End of millennium: The information age: Economy, society and culture, volume III, $2^{\text {nd }}$ ed. Oxford: Blackwell

De Vos, A S (ed) 1998. Research at grass roots: A primer for the caring professions. Pretoria: Van Schaik.

Dekker, G 2000. Zodat de wereld verandert: Over de toekomst van de kerk. Baarn: Ten Have.

Die Burger, 16 September 2005. Wêreldregerings "steek af by SA," $p 7$.

Easum, W M \& Bandy, T G 1997. Growing spiritual redwoods. Nashville, TN: Abingdon.

Elliott, C 1987. Comfortable compassion: Poverty, power and the church. London: Hodder.

Erasmus, J C, Hendriks, H J \& Mans, G G 2006. Religious research as kingpin in the fight against poverty and Aids in the Western Cape, South Africa. HTS 62(1), 293-311.

Fowler, J W 1999. The emerging new shape of practical theology, 75-92, in Schweitzer, F \& Van der Ven, J A, Practical Theology: International perspectives. Frankfurt: Peter Lang. 
Froise, M \& Hendriks, H J (eds) 1999. South African Christian Handbook 1999-2000. Welkom: Christian Info.

Glasser, A F 2003. Announcing the Kingdom: The story of God's mission and the Bible. Grand Rapids, Ml: Baker.

Guder, D L (ed) 1998. Missional church. Grand Rapids, MI: Eerdmans.

Hall, J D 1991. Thinking the faith: Christian theology in a North American context. Minneapolis, MN: Fortress.

Hall, J D 1993. Professing the faith: Christian theology in a North American context. Minneapolis, MN: Fortress.

Hall, J D 1996. Confessing the faith: Christian theology in a North American context. Minneapolis, MN: Fortress.

Hanson P D 1986. The people called: The growth of community in the Bible. San Francisco, CA: Harper.

Hauerwas, S \& Willimon, W H 1989. Resident aliens: Life in the Christian colony. Nashville, TN: Abingdon.

Hendriks, H J \& Erasmus, J C (eds) 2003. Religious affiliation in South Africa early in the new millennium: Markinor's World Values Survey. JTSA 117, 80-96.

Hendriks, H J \& Erasmus J C 2005. Religion in South Africa: The 2001 population census data. JTSA 121, 88-111.

Hendriks, H J, Erasmus J C \& Mans G G 2004. Congregations as providers of social service and HIV/AIDS care. NGTT 45(2). (supple 380-402.)

Hendriks, H J 1992. Strategiese beplanning in die gemeente. Wellington: Hugenote.

Hendriks, H J 2004. Studying congregations in Africa. Wellington: Lux-Verbi-BM.

Hunsberger, G R \& Van Gelder, C (eds) 1996. Church between gospel and culture. Grand Rapids, MI: Eerdmans.

Jenkins, P 2002. The next Christendom: The coming of global Christianity. Oxford: Oxford.

Kelsey, D 1992. To understand God truly. Louisville, KY: Westminster.

Korten, D C 1995. When corporations rule the world. West Hartford: Kumarian.

Louw, D J 1998. A pastoral hermeneutics of care and encounter. Cape Town: Lux Verbi.

Makgoba, M W (ed) 1999. African Renaissance. Cape Town: Mafube-Tafelberg.

McLaren B D 2000. The church on the other side: Doing ministry in the postmodern matrix. Grand Rapids, Ml: Zondervan.

Mead, L B 1996. Five challenges for the once and future church. Washington DC: Alban.

Mead, L B 1991. The once and future church: Reinventing the congregation for a new mission frontier. Washington DC: Alban Institute.

Mouw, R J 1994. Consulting the faithful: What Christian intellectuals can learn from popular religion. Grand Rapids, MI: Eerdmans.

Newbigin, L 1995. Proper confidence, faith, doubt \& certainty in Christian discipleship. Grand Rapids, MI: Eerdmans.

Newbigin, L 1989. The Gospel in a pluralist society. Grand Rapids, Ml: Eerdmans.

Newbigin, L 1995 [1978]. The open secret: An introduction to the theology of mission. Grand Rapids: Eerdmans.

Ploeger, A 1999. Practical theological theory and the praxis of the church. International Journal of Practical Theology 3, 68-93.

Radoli, A 1998 (Editorial). African Ecclesial Review 40(5\&6), 257. 
Rasmussen, L L 1993. Moral fragments and moral community: A proposal for church in society. Minneapolis, MN: Fortress.

Rasmussen, L L 1996. Earth community, earth ethics. Maryknoll, NY: Orbis.

Roxburgh, A J 2005. The sky is falling!?!: Leaders lost in transition. Eagle, ID: Allelon.

Sanneh, L 2003. Whose religion is Christianity: The Gospel beyond the West. Grand Rapids, MI: Eerdmans.

Schwarz, C A 1999. Paradigm shift in the church: How natural church development can transform theological thinking. Carol Stream: Church Smart Resources.

Stark, R 1997. The rise of Christianity. San Francisco, CA: Harper Collins.

Stremlau, J 1999. African Renaissance and international relations, in Makgoba, M W (ed), 101-124. Cape Town: Mafube Tafelberg.

Sweet, L 1999. Soultsunami: Sink or swim in new millennium culture. Grand Rapids, $\mathrm{Ml}$ : Zondervan.

Symington, J, Hendriks H J, \& Erasmus, J C 2005. 2005-2006 South African Christian Handbook. Wellington: Tydskriftemaatskappy.

Tracy, D 1981. The analogical imagination: Christian theology and the culture of pluralism. New York: Crossroads.

Van der Ven, J 1998. Practical Theology: An empirical approach. Leuven: Peeters.

Walls, A F 2002. The cross-cultural process in Christian History. Maryknoll, NY: Orbis.

West, G 1994. The Bible and theology, in De Gruchy, J W \& Villa-Vicencio, C (eds), Doing theology in context: South African perspectives, 15-25. Cape Town: David Philip. 